\title{
Decontamination of T-2 Toxin in Maize by Modified Montmorillonite Clay
}

\author{
Bunmi K. Olopade ${ }^{1, *}$, Solomon U. Oranusi ${ }^{1}$, Obinna C. Nwinyi ${ }^{1,2}{ }^{\circledR}$, Isiaka A. Lawal ${ }^{3} \mathbb{C}_{\text {, }}$ \\ Sefater Gbashi ${ }^{2}$ and Patrick B. Njobeh ${ }^{2}$ (I) \\ 1 Department of Biological Sciences, Covenant University, Ota 112233, Ogun State, Nigeria; \\ solomon.oranusi@covenantuniversity.edu.ng (S.U.O.); obinna.nwinyi@covenantuniversity.edu.ng (O.C.N.) \\ 2 Department of Biotechnology and Food Technology, University of Johannesburg, Doornfontein Campus, \\ Gauteng 2028, South Africa; sefatergbashi@gmail.com (S.G.); pnjobeh@uj.ac.za (P.B.N.) \\ 3 Chemistry Department, Faculty of Applied and Computer Science, Vaal University of Technology, \\ Vanderbijlpark Campus, Boulevard, Vanderbijlpark 1900, South Africa; lawalishaq000123@yahoo.com \\ * Correspondence: bunmi.olopade@covenantuniversity.edu.ng
}

Received: 8 September 2019; Accepted: 21 October 2019; Published: 24 October 2019

check for updates

\begin{abstract}
Montmorillonite clay has a wide range of applications, one of which includes the binding of mycotoxins in foods and feeds through adsorption. T-2 toxin, produced by some Fusarium, Myrothecium, and Stachybotrys species, causes dystrophy in the brain, heart, and kidney. Various formulations that include lemongrass essential oil-modified montmorillonite clay (LGEO-MMT), lemongrass powder (LGP), montmorillonite clay washed with $1 \mathrm{mM} \mathrm{NaCl}$ (Na-MMT), montmorillonite clay (MMT), and lemongrass powder mixed with montmorillonite clay (LGP-MMT) were applied to maize at concentrations of $8 \%$ and $12 \%$ and stored for a period of one month at $30{ }^{\circ} \mathrm{C}$. Unmodified montmorillonite clay and LGP served as the negative controls alongside untreated maize. Fourier Transform Infrared (FTIR) spectra of the various treatments showed the major functional groups as $\mathrm{Si}-\mathrm{O}$ and $-\mathrm{OH}$. All treatment formulations were effective in the decontamination of T-2 toxin in maize. Accordingly, it was revealed that the inclusion of Na-MMT in maize at a concentration of $8 \%$ was most effective in decontaminating T-2 toxin by $66 \%$ in maize followed by LGP-MMT at $12 \%$ inclusion level recording a $56 \%$ decontamination of T-2 toxin in maize $(p=0.05)$. Montmorillonite clay can be effectively modified with plant extracts for the decontamination of T-2 toxin.
\end{abstract}

Keywords: decontamination; adsorption; T-2 toxin; montmorillonite clay; Cymbopogon citratus; maize

Key Contribution: A green method was successfully employed for the decontamination of T-2 toxin using montmorillonite clay in combination with $\mathrm{Na}^{+}$ions, and montmorillonite clay in combination with extracts and powder of Cymbopogon citratus.

\section{Introduction}

Maize is grown worldwide, with the United States, China, and Brazil ranked as the leading producing countries contributing approximately 563 of the 717 million metric tonnes per year [1]. However, maize, like other cereals, is susceptible to contamination by mycotoxins, including T-2 toxin. T-2 toxin is common in grains, including oats, soybeans, rice, barley, maize, and wheat [2]. Fusarium langsethiae and F. sporotrichioides are some of the Fusarium species that infect crops in the field and storage during which time they produce T-2 toxin [3]. This toxin belongs to the family of mycotoxins known as the trichothecenes produced mainly by Fusarium sporotrichioides, F. graminearum, F. poae, and F. culmorum and causing diarrhea, inflammation, and emesis [4,5]. They can be grouped into Type A, B, C, and D, with T-2 toxin belonging to Type A trichothecenes, the most toxic group of trichothecenes. Trichothecenes are among the mycotoxins associated with human and veterinary diseases [6]. Like T-2, 
all trichothecenes have a common tetracyclic sesquiterpenoid 12,13-epoxytrichothec-9-ene ring system together with an epoxide group located at their C12, C13 positions, which accounts for their toxicity [7]. T-2 toxicity is induced via oxidative stress-mediated deoxyribonucleic acid (DNA) damage and apoptosis [8]. The chemical structure of T-2 toxin is shown in Figure 1.

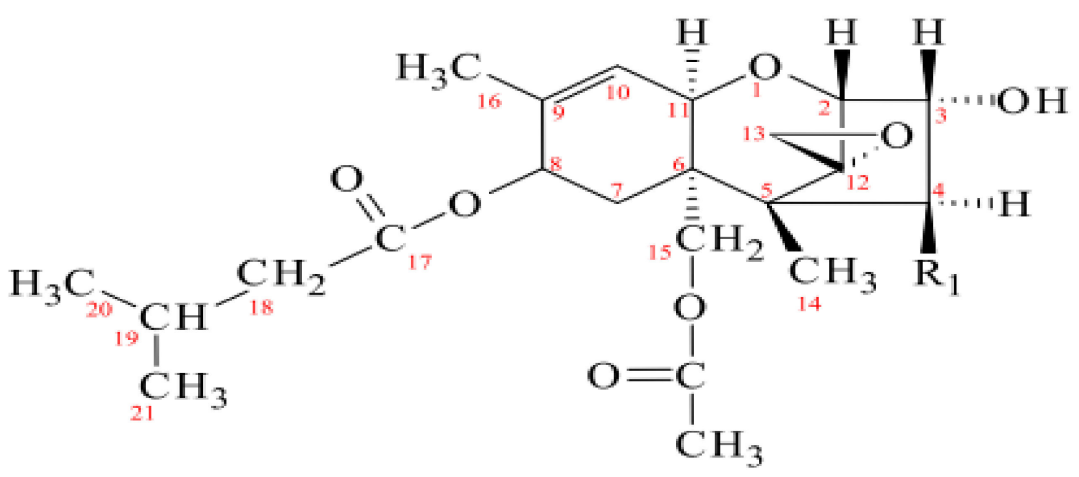

Figure 1. Chemical structure of T-2 toxin (R1 = OAc) adapted from European Food Safety Authority (2011).

T-2 toxin is a recognized inhibitor of protein synthesis, which occurs by the binding of peptidyl transferase, present in the $60 \mathrm{~S}$ ribosomal subunit [9]. T-2 poisoning in man results in alimentary toxic aleukia (ATA). The toxin also causes ulcers as well as necrosis in the digestive tract, hemorrhagic inflammation, and dystrophy in the brain, heart, kidney, and liver [10]. The walls of blood vessels are damaged, provoking hemorrhagic diathesis [10]. T-2 also affects animals, with monogastric animals being more susceptible than ruminants. This is because ruminants, such as cattle, possess a rumen where de-acetylation and de-epoxidation of the toxin take place, thus limiting its toxicity [11]. The toxin also affects poultry, causing ulcerative and necrotic lesions as well as oral lesions, thereby leading to refusal of feed [12]. Studies have revealed that T-2 toxin is easily absorbed in the intestinal tract and is toxic to the organs of animals affecting the digestive system and liver of animals [13,14].

Decontamination processes involving physical, biological, and chemical methods are frequently required for the removal, destruction, and decontamination of mycotoxins [15]. Biological approaches include the activity of microorganisms (algae, bacteria, filamentous fungi, and yeasts) against mycotoxins using antibiosis or competition for nutrients and space [15]. Chemical approaches help to degrade mycotoxins by various gases, aldehydes, oxidizing agents, acids, and bases. The EC supports the application of physical methods and sorting procedures for decontaminating mycotoxins [16]. However, neither the mixing of batches to reduce mycotoxins to levels below the maximum tolerable limits nor decontamination using chemicals is permitted by the European Union [16]. Physical methods of detoxification include irradiation (gamma or ultraviolet irradiation), solvent extraction, inactivation by heat, and the use of mineral adsorbents (mainly clays) [17]. The disadvantages of food irradiation are the high costs involved and loss of vitamins (avitaminosis), while inactivation by heat may lead to a loss in nutritional properties of the commodities [18]. The use of mineral adsorbents, such as clay, is a cheaper and safer alternative to these methods, revealing their mycotoxin decontamination properties. Clays also serve as anti-caking agents in animal feed, and they are highly regarded as effective mycotoxin binding agents in animal feeds by enterosorption [19]. Enzymes such as oxidoreductases and hydrolases have also been thoroughly explored in the mitigation of mycotoxins in animal feed [20].

Montmorillonite clay has pharmaceutical applications where it serves as an excipient in drugs for oral or topical use [21]. The cytotoxicity of montmorillonite clay is low both in vitro and in vivo [22]. A study by Wei et al. [23] showed that modified hydrated sodium calcium aluminosilicate (HSCAS) adsorbent could be used in vivo to reduce toxicity induced by T-2 toxin. Therefore, clay can be safely expended in the storage of cereal crops for mycotoxin decontamination purposes. Montmorillonite, when compared with other nanoclays, has an advantage because it is abundant and environmentally friendly [24]. Each layer of montmorillonite has a lateral dimension of 200-600 nm. It is made up of an octahedral sheet sandwiched between two tetrahedral sheets. The arrangement of the sheets 
is such that the silicon oxide tetrahedron $\left(\mathrm{SiO}_{4}\right)$ shares three out of four of its oxygen atoms with the central octahedral sheets [24]. Among various clay minerals such as kaolinite, illite, and chlorite, montmorillonite is more ideal for adsorption studies since it has a high cation exchange capacity, swelling capacity, and high surface area $[25,26]$.

The use of plant extracts may have ancillary effects, thus preventing fungal growth and the production of mycotoxins. The oils of plants such as anise, basil, cinnamon, lemon, clove, lemongrass, spearmint, and oregano have been shown to inhibit fungi that produce $\mathrm{DON}, \mathrm{FB}_{1}$, and ZEA [27]. Cymbopogon citratus (lemongrass) has been expended in the decontamination of Aspergillus species and limit AF production in maize [28]. Traditionally, lemongrass tea is consumed in South America, Asia, and West Africa, having anti-fever, anti-inflammatory, antiseptic, anti-dyspeptic, and carminative properties [29] with no toxicity reported both in animal and man. Fandohan et al. [30] revealed that the lethal dose (LD50) for lemongrass is $>3500 \mathrm{mg} / \mathrm{kg}$ bw and is likely to cause hepatocyte necrosis, leukocytes infestation of liver parenchyma, and alteration of stomach structure in rats. Therefore, extracts and powder of Cymbopogon citratus can be safely used in the decontamination of mycotoxins in cereals. The aim of this study, therefore, was to decontaminate T-2 toxin in maize using formulations from montmorillonite clay together with extracts and powder of Cymbopogon citratus.

\section{Results and Discussion}

\subsection{Scanning Electron Microscopy}

The scanning electron micrographs of the various treatment formulations with a magnification of $500 \times$ and scale bar of $100 \mu \mathrm{m}$ are shown in Figure 2a-e. The morphologies of the various formulations were similar and appeared as agglomerates. Unmodified montmorillonite (MMT) and Na-MMT had very similar morphology, while LGEO-MMT appeared more agglomerated than the other treatments because of fatty acids present in the crude extracts of Cymbopogon citratus. 

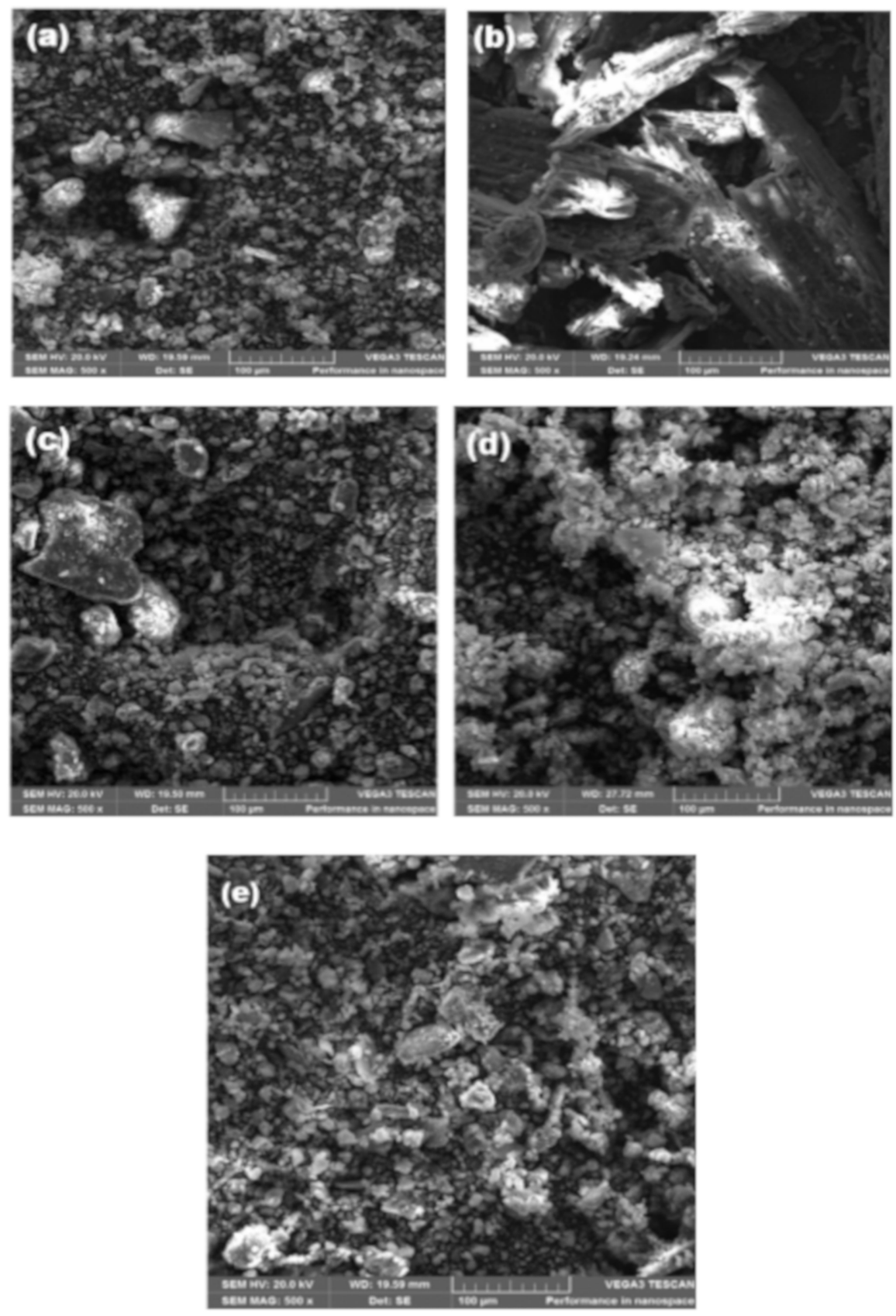

Figure 2. (a) Montmorillonite clay (MMT); this figure was published previously in Olopade et al. (2019). (b) Lemongrass powder (LGP); this figure was published previously in Olopade et al. (2019). (c) Montmorillonite clay washed with $\mathrm{NaCl}(\mathrm{Na}-\mathrm{MMT})$; this figure was published previously in Olopade et al. (2019). (d) Montmorillonite clay with lemongrass essential oil (LGEO-MMT); this figure was published previously in Olopade et al. (2019). (e) Montmorillonite mixed with Lemongrass powder (LGP-MMT); this figure was published previously in Olopade et al. (2019).

\subsection{Fourier Transform Infrared (FTIR) Spectroscopy}

The Infrared spectra of lemongrass essential oil-modified montmorillonite clay (LGEO-MMT), lemongrass powder (LGP), sodium montmorillonite (Na-MMT), montmorillonite clay (MMT), and lemongrass powder mixed with montmorillonite (LGP-MMT) are shown in Figure 3. There were visible bands at 459.52 and $1029.52 \mathrm{~cm}^{-1}$ and a little depression along $3392.10 \mathrm{~cm}^{-1}$ for all the treatments containing montmorillonite clay. The bands at $1737 \mathrm{~cm}^{-1}, 1620 \mathrm{~cm}^{-1}$, and $1515 \mathrm{~cm}^{-1}$ in LGP, as shown in Figure 3, were attributed to the aliphatic, aromatic, and ester functional groups, respectively, which are 
present in the hemicellulose, wax, and pectin, as reported by Sun et al. [31]. The dominant spectrum at $3420 \mathrm{~cm}^{-1}$ corresponds to the $\mathrm{O}-\mathrm{H}$ stretch, which is an aliphatic stretch in moieties of cellulose. The band at about $1739 \mathrm{~cm}^{-1}$ is due to the $\mathrm{C}=\mathrm{O}$ stretching of the acetyl group and linked to the ester linkage of the carboxylic group of the ferulic acid and p-coumaric acid of lignin [31]. The broad band between 3200 and $3500 \mathrm{~cm}^{-1}$ represents that of an aliphatic compound attached to a hydroxyl $(\mathrm{OH})$ group [32]. The $\mathrm{OH}$ functional group is usually present in alcohols, phenols, and carboxylic acids. However, the $\mathrm{OH}$ functional group in this spectrum neither belongs to a phenol nor a carboxylic acid because there is an absence of both benzene and carbonyl bands in the spectrum, respectively. The -OH in this spectrum belongs to alcohol. The IR spectrum of an alcohol is characterized by a strong and broad O-H stretch between $3300-3500 \mathrm{~cm}^{-1}$ [32]. The infrared (IR) spectrum of LGEO-MMT and Na-MMT, as shown in Figure 3, revealed that the peaks at 459 and $1029 \mathrm{~cm}^{-1}$ represent the bands for Si-O-Si bending and stretching, respectively [33]. These bands were present in two of the modified montmorillonite clays. The peaks in the region $3392 \mathrm{~cm}^{-1}$ represent the stretching of the $-\mathrm{OH}$ (hydroxyl group) of water within MMT [33]. Thus, Si-O bonds may be involved in the decontamination of T-2 by supplying energy to the van der Waals forces within the interlayer spaces of clay to enable the attraction of T-2 toxin.

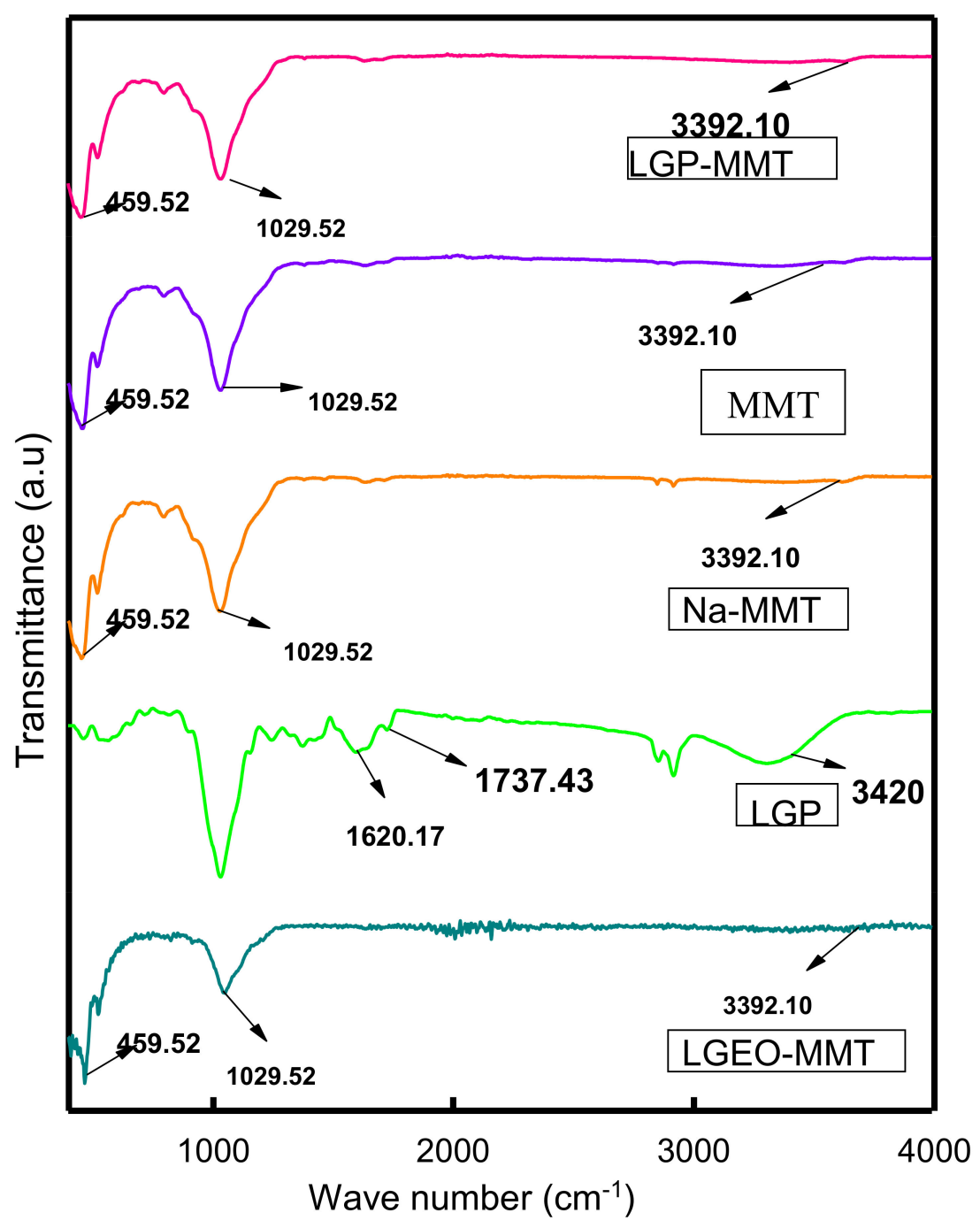

Figure 3. Fourier Transform Infrared (FTIR) spectra of LGEO-MMT, LGP, Na-MMT, MMT, and LGP-MMT. 


\subsection{The Decontamination of T-2 Toxin in Maize}

T-2 toxin had an apparent recovery of $116 \%$. Its limit of detection (LOD) was $0.002 \mu \mathrm{g} / \mathrm{kg}$, while its limit of quantification (LOQ) was $0.006 \mu \mathrm{g} / \mathrm{kg}$. The various types of treatment (LGEO-MMT, LGP, Na-MMT, MMT, and LGP-MMT) applied to the maize sample from the same batch were effective over the treatment period of four weeks. The storage temperature $\left(30^{\circ} \mathrm{C}\right)$ was maintained for the treated maize samples and the control (untreated maize) throughout the four weeks of storage. The experiments were run for four weeks to establish the trend in the decontamination of T-2 toxin with time. The control (untreated maize stored under similar conditions as treated samples) remained unchanged throughout the treatment period from the first to the fourth week with a concentration of $30 \mathrm{ppb}$ (Figures 4 and 5).

The Post-Hoc analysis data generated showed significant differences among the five treatments against T-2 toxin. Further statistical analysis using LSD to compare mean values among various treatment formulations for the decontamination of T-2 toxin revealed that sodium montmorillonite (Na-MMT) was the most effective against T-2 toxin $(p=0.05)$. Montmorillonite clay, which has high adsorptive properties along with the positive charge of sodium $\left(\mathrm{Na}^{+}\right)$, could have led to the effective trapping of T-2 toxin. It appears that the decontamination of T-2 toxin is better achieved by adsorption. Regular van der Waals gap between the sheets of clay is referred to as the interlayer spaces that possess a net negative charge due to ionic substitutions in the sheets of clay minerals [24]. Furthermore, the interlayer spaces can be assessed by water, organic cations, or polar organic liquids.

Sodium montmorillonite (Na-MMT) was more effective than the unmodified montmorillonite (MMT) due to the presence of $\mathrm{Na}^{+}$ion, an alkali metal ion, which made the clay electrically neutral. Thus, the electrically neutral clay enhanced the binding of T-2 toxin. Silicates, which include montmorillonite clay being electrically negative, combine with ions, especially cations of alkali and alkali earth elements, to form electrically neutral species [34]. Lemongrass essential oil-modified montmorillonite clay (LGEO-MMT) at a concentration of $12 \%$ was the second most effective treatment against T- 2 toxin. Hence, the decontamination of T-2 in maize was most effective throughout the period of four weeks in the following descending order: Na-MMT (8\%), LGP-MMT (12\%), MMT (12\%), LGP (12\%), and LGEO-MMT (12\%), with 66\%, $56 \%, 48 \%, 42 \%$, and $37 \%$ decontamination, respectively. For LGP-MMT at $12 \%$, which was the second most efficient in the decontamination of T-2 toxin, the powder of Cymbopogon citratus in combination with montmorillonite clay contributed towards making montmorillonite clay more hydrophobic than the unmodified montmorillonite. Erminawati et al. [35] revealed that lemongrass contains hydrophobic compounds, including z-citral, estragole, borneol, methyl eugenol, beta-myrcene (MYR, 7-methyl-3-methylene-1,6 octadiene), geranyl acetate (3,7-dimethyl-2,6-octadiene-1-ol acetate), geraniol, limonene piperitone, citrat-2, citronellal, alpha-terpineole, proximal, pinene, farnesol, and (+)cymbodiacetal [36]. Type A-trichothecenes (T-2 and HT-2) are non-polar, while Type B-trichothecenes (DON, NIV) are polar [37]. T-2, being a non-polar mycotoxin, attracts hydrophobic compounds. Hence, its ability to bind to the surface of the LGP-MMT, which contains hydrophobic compounds.

Microbiological approaches for the decontamination of T-2 toxin include the use of bacteria such as Rhodococcus erythropolis, Rhodococcus globerulus, Rhodococcus rhodochrous, and Rhodococcus coprophilus. These bacteria were $90 \%$ efficient in the degradation of T-2 toxin, although their degradation products were not studied [38]. Other bacteria such as species of Pseudomonas, Arthrobacter, Blastobacter, and those from the family Rhizobiaceae, have also been employed in the elimination of T-2 toxin with $100 \%$ efficiency recorded. However, Wachowska et al. [39] reported that degradation products such as Neosolaniol (NEO), T-2 tetraol, and T-2 Triol were produced. These T-2 degradation products and residual parent toxins are capable of inducing apoptosis [40]. Hence, the adsorption capacity observed in this study may be more advantageous because there are minimal chances for the formation of degradation products from T-2 toxin. Rather, the mycotoxin is adsorbed onto the surface of the modified montmorillonite clay, and the products formed are then excreted via feces. In addition, it is worth noting herein that the best way to protect foods and feeds against mycotoxins is to monitor their presence in foods and feeds. Therefore, regular routine analysis of food and feed for mycotoxins and control are recommended [41]. 


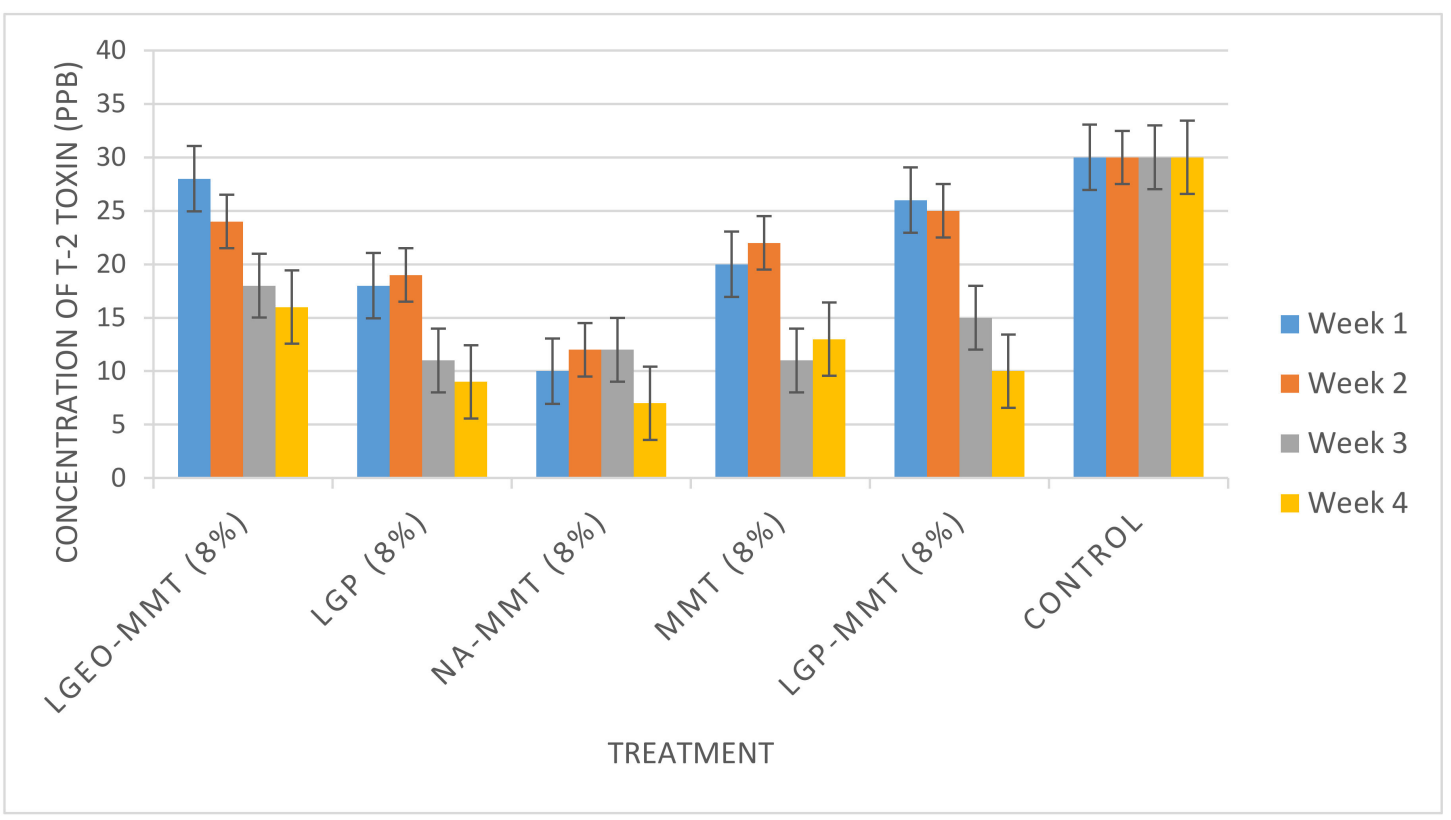

Figure 4. Evaluation of T-2 toxin after treatment with $8 \%$ of various types of modified clay for 4 weeks. LGEO-MMT: Lemongrass essential oil-modified montmorillonite clay; LGP: lemongrass powder; Na-MMT: montmorillonite clay washed with $1 \mathrm{mM} \mathrm{NaCl}$; MMT: montmorillonite clay; LGP-MMT: lemongrass powder mixed with montmorillonite clay.

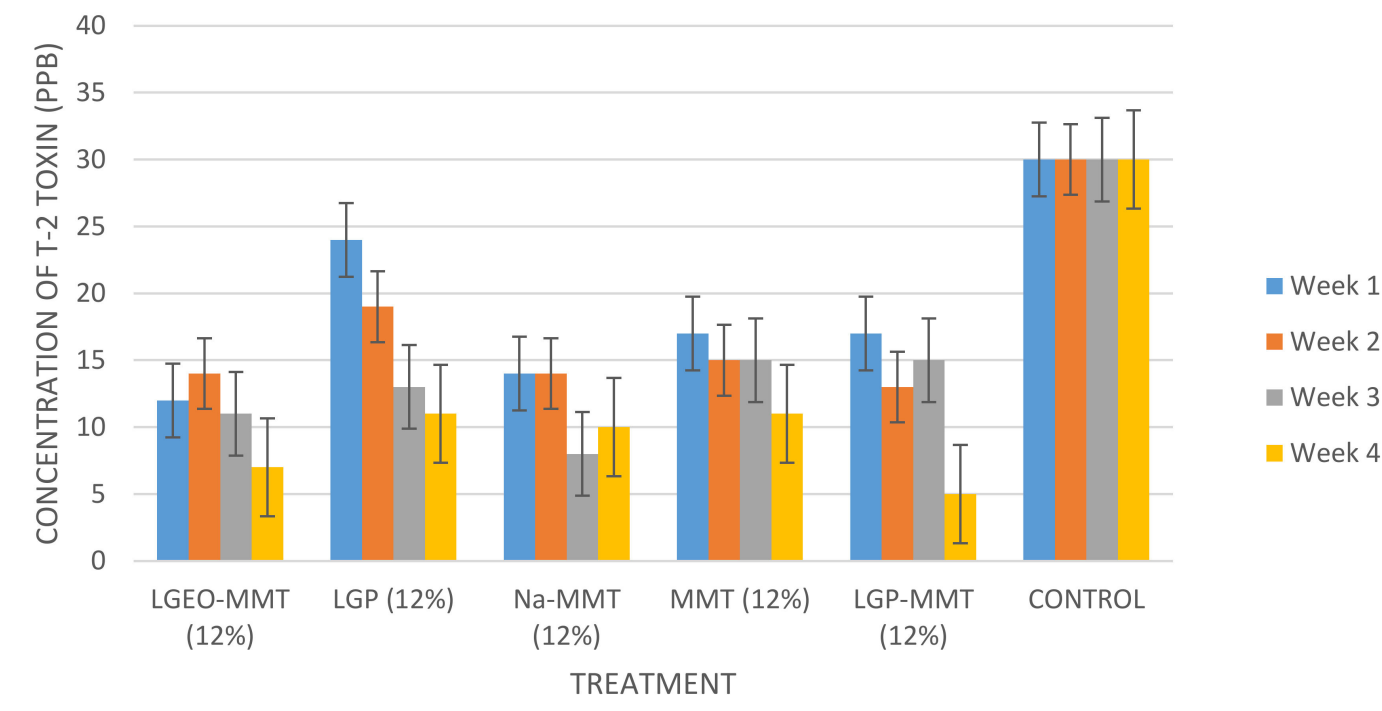

Figure 5. Evaluation of T-2 toxin after treatment with $12 \%$ of various types of modified clay for 4 weeks. LGEO-MMT: Lemongrass essential oil-modified montmorillonite clay; LGP: lemongrass powder; Na-MMT: montmorillonite clay washed with $1 \mathrm{mM} \mathrm{NaCl}$; MMT: montmorillonite clay; LGP-MMT: lemongrass powder mixed with montmorillonite clay. 


\section{Conclusions}

Montmorillonite clay was successfully modified on the surface with a sodium $\left(\mathrm{Na}^{+}\right)$ion, which made the clay electrically neutral and able to trap T-2 toxin especially, with sodium montmorillonite (Na-MMT) noted as the most efficient in decontaminating T-2 toxin in maize. Hence, the trapping of T-2 toxin was achieved by the regular van der Waals forces between the sheets of Na-MMT, which were enhanced by the Si-O bonds for the entrapment of this toxin within its layers. Adsorption processes for the decontamination of T-2 appear more promising than the biological methods for its decontamination because there could be very limited chances for the formation of toxic products.

\section{Materials and Methods}

\subsection{Chemicals and Reagents}

The chemicals used in this study were of analytical grade. These include: Methanol and Acetonitrile (LiChrosolv Reag. Ph Eur, Merck, Darmstadt, Germany, 99.9\%), Formic acid (Fluka 56302-50ML-F, p. a, Thermofisher Inc, Oslo, Norway, 99.9\%), Hexane (pro analyse, Merck, Darmstadt Germany, 99.9\%); Acetone (HPLC grade, 99.8\%, Sigma-Aldrich, Darmstadt Germany), Sodium chloride salt, and deionized water. T-2 mycotoxin standard was purchased from Sigma-Aldrich (Bornem, Belgium). Maize samples were purchased from one of the grain hubs in Ogun state, and a screening was performed to identify a maize sample that was naturally contaminated with T-2 toxin. The naturally contaminated T-2 maize sample was utilized for the experiment.

\subsection{Sample Preparation}

Montmorillonite K10 powder (CAS number 1318-93-0 (Sigma-Aldrich) was purchased, while Cymbopogon citratus (lemongrass) leaves used for the study were identified at the Botany Unit of the Department of Biological Sciences, Covenant University, Nigeria.

Montmorillonite clay K10 and lemongrass powder were the negative controls for the treatment. Fresh leaves of Cymbopogon citratus were gently washed with distilled water to remove dirt, and the leaves were allowed to air-dry at room temperature for 3 weeks. The dried leaves were ground into powder by using an electric blender (IKA M20, Wilmington, NC, USA). The lemongrass extracts were obtained by the Soxhlet extraction method described by Ojewumi et al. [42]. The dry powder of lemongrass $(25 \mathrm{~g})$ was extracted with $250 \mathrm{~mL}$ of hexane. The lemongrass extract was concentrated using a rotary evaporator (IKA RV10, Staufen, Germany) to obtain the essential oil used for the preparation of LGEO-MMT, which was done according to the method of Noudem et al. [43] with slight modification. All the formulations used for the decontamination of T-2 in the maize samples were prepared as described in Olopade et al. [44]. The montmorillonite clay was homogenized at $25^{\circ} \mathrm{C}$ with a $\mathrm{NaCl}$ solution $\left(1 \mathrm{~mol} \mathrm{~L}^{-1}\right)$, at a solid:liquid ratio of $1 / 20$. After that, the mixture was dialyzed in deionized water to eliminate chloride ions. The dialyzed samples were gently dried at $40{ }^{\circ} \mathrm{C}$ to allow for a gradual loss of water from the clay. In a $500 \mathrm{~mL}$ flask, $25 \mathrm{~g}$ of the clay powder was dispersed in $50 \mathrm{~mL}$ of essential oil solution $(v / v)$ prepared with acetone. The mixture was whirled at room temperature $\left(25^{\circ} \mathrm{C}\right)$ in an overhead shaker at 50 revolutions per min. Afterward, the mixture was placed in a water bath operated at $60^{\circ} \mathrm{C}$ for $90 \mathrm{~min}$ to allow for the evaporation of acetone. The mixture (LGEO-MMT) was dried overnight at $30^{\circ} \mathrm{C}$, and then stored in colored and tightly sealed vials using aluminum foil.

For the Na-MMT mixture, montmorillonite clay was modified by washing the clay with $1 \mathrm{mM}$ $\mathrm{NaCl}$ solution in the ratio $1 / 20(w / v)$, while LGP-MMT was prepared by mixing lemongrass powder with montmorillonite clay in the ratio 1:1. 


\subsection{Fourier Transform Infrared (FTIR) Spectroscopy}

Fourier Transform Infrared (FTIR) Spectroscopy of the clay samples was performed with the aid of a Perkin Elmer Spectrum 100 FTIR Spectrometer. One drop of Nujol (a liquid hydrocarbon) was added to $1 \mathrm{mg}$ of each sample and mixed thoroughly. The mull was then placed between sodium chloride plates, and the spectrum was recorded.

\subsection{Scanning Electron Microscopy (SEM)}

The samples were coated with carbon and examined with the aid of VEGA3 TESCAN scanning electron microscope at a voltage of $20 \mathrm{kV}$ and magnification of $500 \times$ to examine their morphology.

\subsection{Evaluation of T-2 Toxin before Treatment}

For the method validation of T-2 toxin, the apparent recovery (AR) was obtained by spiking a known amount of T-2 toxin to a blank. The blank was spiked with 0.25 and $1 \mu \mathrm{L}$ of the T-2 reference standard within a calibration range of $156.25-5000 \mu \mathrm{g} / \mathrm{kg}$. The limit of detection (LOD) and limit of quantification (LOQ) were also determined.

Liquid chromatography-tandem mass spectrometry (LC-MS/MS) protocol, as reported by Sulyok et al. [45], was used to quantify T-2 toxin in maize before applying the various types of treatment (LGEO-MMT, LGP, Na-MMT, MMT, and LGP-MMT). In a $50 \mathrm{~mL}$ polypropylene tube (Sarstedt, Nümbrecht, Germany), $5 \mathrm{~g}$ of ground maize sample was extracted using $20 \mathrm{~mL}$ of an extraction solvent consisting of acetonitrile/water/formic acid (79:20:1, v/v/v) for $90 \mathrm{~min}$ on a GFL 3017 rotary shaker (GFL, Burgwedel, Germany). Five hundred $\mu \mathrm{L}$ of each filtered extract was then injected into the LC-MS/MS system to determine the level of T-2 toxin.

\subsection{Decontamination of T-2 Toxin in Maize}

Each of the various treatment formulations (LGEO-MMT, LGP, Na-MMT, MMT, and LGP-MMT) were applied to the maize sample in duplicates at $8 \%$ and $12 \%$ and stored for 4 weeks at a temperature of $30{ }^{\circ} \mathrm{C}$ in the incubator following the modified method of Atanda and Olopade [28]. A control was set up by subjecting the untreated maize sample from the same batch to the same condition of storage at $30{ }^{\circ} \mathrm{C}$, just like the treated maize samples. LC-MS/MS protocol, as reported by Sulyok et al. [45], was used to quantify the levels of T-2 in the treated maize samples at the end of the first, second, third, and fourth weeks.

\subsection{Statistical Analysis}

The efficacy of the various types of treatment, which were applied in duplicates, was determined by Post-Hoc analysis using the IBM SPSS statistics software (ver. 23, 2015 Inc., Chicago, IL, USA). Subsequently, mean values among the various treatment formulations for the decontamination of T-2 toxin were compared by the Least Significant Difference (LSD) test and considered to differ at $p \leq 0.05$.

Author Contributions: Conceptualization, B.K.O., S.U.O., O.C.N.; methodology, B.K.O., I.A.L. and S.G., software, B.K.O., I.A.L. and S.G.; validation, B.K.O. and S.G.; formal analysis, B.K.O., S.G. and I.A.L.; funding acquisition, P.B.N. original draft preparation, B.K.O.; resources, B.K.O., P.B.N. and I.A.L. writing-review and editing, S.U.O., O.C.N., P.B.N., S.G. and I.A.L.; supervision, S.U.O., O.C.N. and P.B.N.

Funding: The authors are grateful to LEAP-Agri and National Research Foundation of South Africa Co-funded project: Towards Europe Africa Funding and Research Alliances as well as Covenant University, Nigeria, for their support towards the publication of this work.

Acknowledgments: The authors would like to thank Riaan Meyer and Darryl Harris from Shimadzu, South Africa for their technical assistance, and Covenant University, Nigeria for the financial support towards the publication of this work.

Conflicts of Interest: All authors declare no conflict of interest in this paper. 


\section{Abbreviations}

$\begin{array}{ll}\text { Bw } & \text { body weight } \\ \text { LGEO-MMT } & \text { lemongrass essential oil-modified montmorillonite clay } \\ \text { LGP } & \text { lemongrass powder } \\ \text { Na-MMT } & \text { montmorillonite clay washed with } 1 \mathrm{mM} \mathrm{NaCl} \\ \text { MMT } & \text { montmorillonite clay } \\ \text { LGP-MMT } & \text { lemongrass powder mixed with montmorillonite clay } \\ \text { FTIR } & \text { Fourier Transform Infrared Spectroscopy } \\ \text { LSD } & \text { Least Significant Difference } \\ \text { AF } & \text { Aflatoxin } \\ \text { NEO } & \text { neosolaniol } \\ \text { DON } & \text { deoxynivalenol } \\ \text { FB } 1 & \text { fumonisin } B_{1} \\ \text { NIV } & \text { nivalenol } \\ \text { ZEA } & \text { zearalenone }\end{array}$

\section{References}

1. Ranum, P.; Pena-Rosas, J.P.; García-Casal, M.N. Global maize production, utilization, and consumption. Ann. N. Y. Acad. Sci. 2014, 1312, 105-112. [CrossRef] [PubMed]

2. Krska, R.; Malachova, A.; Berthiller, F.; Van Egmond, H. Determination of T-2 and HT-2 toxins in food and feed: An update. World Mycotoxin J. 2014, 7, 131-142. [CrossRef]

3. Bertero, A.; Moretti, A.; Spicer, L.J.; Caloni, F. Fusarium Molds and Mycotoxins: Potential Species-Specific Effects. Toxins 2018, 10, 244. [CrossRef] [PubMed]

4. Antonissen, G.; Martel, A.; Pasmans, F.; Ducatelle, R.; Verbrugghe, E.; Vandenbroucke, V.; Li, S.; Haesebrouck, F.; Van Immerseel, F.; Croubels, S. The Impact of Fusarium Mycotoxins on Human and Animal Host Susceptibility to Infectious Diseases. Toxins 2014, 6, 430-452. [CrossRef] [PubMed]

5. Tamura, M.; Mochizuki, N.; Nagatomi, Y.; Harayama, K.; Toriba, A.; Hayakawa, K. A Method for Simultaneous Determination of 20 Fusarium Toxins in Cereals by High-Resolution Liquid Chromatography-Orbitrap Mass Spectrometry with a Pentafluorophenyl Column. Toxins 2015, 7, 1664-1682. [CrossRef]

6. Oranusi, S.U.; Olarewaju, S.A. Mycoflora and aflatoxin contamination of some foodstuffs. Int. J. Biotechnol. Allied Fields 2013, 1, 9-18.

7. Nathanail, A.V.; Varga, E.; Meng-Reiterer, J.; Bueschl, C.; Michlmayr, H.; Malachova, A.; Fruhmann, P.; Jestoi, M.; Peltonen, K.; Adam, G.; et al. Metabolism of the Fusarium Mycotoxins T-2 Toxin and HT-2 Toxin in Wheat. J. Agric. Food Chem. 2015, 63, 7862-7872. [CrossRef]

8. Wu, Q.-H.; Wang, X.; Yang, W.; Nussler, A.K.; Xiong, L.-Y.; Kuca, K.; Dohnal, V.; Zhang, X.-J.; Yuan, Z.-H. Oxidative stress-mediated cytotoxicity and metabolism of T-2 toxin and deoxynivalenol in animals and humans: An update. Arch. Toxicol. 2014, 88, 1309-1326. [CrossRef]

9. Yang, L.; Tu, D.; Zhao, Z.; Cui, J. Cytotoxicity and apoptosis induced by mixed mycotoxins (T-2 and HT-2 toxin) on primary hepatocytes of broilers in vitro. Toxicon 2017, 129, 1-10. [CrossRef]

10. Stoev, S.D.; Diakov, L.; Koynarski, V.; Angelov, A. Special Pathology and Diagnostics of Mycoses, Mycotoxicoses, Parasitoses, Intoxications and Avitaminoses; Publishing House CD Contrast: Stara Zagora, Bulgaria, 2010; pp. 1-239.

11. Agag, B.I. Mycotoxins in foods and feeds. Ass. Univ. Bull. Environ Res. 2005, 8, 107-124.

12. Adhikari, M.; Negi, B.; Kaushik, N.; Adhikari, A.; Al-Khedhairy, A.A.; Kaushik, N.K.; Choi, E.H. T-2 mycotoxin: Toxicological effects and decontamination strategies. Oncotarget 2017, 8, 33933-33952. [CrossRef] [PubMed]

13. Makowska, K.; Obremski, K.; Gonkowski, S. The Impact of T-2 Toxin on Vasoactive Intestinal Polypeptide-Like Immunoreactive (VIP-LI) Nerve Structures in the Wall of the Porcine Stomach and Duodenum. Toxins 2018, 10, 138. [CrossRef] [PubMed]

14. Makowska, K.; Obremski, K.; Zielonka, L.; Gonkowski, S. The Influence of Low Doses of Zearalenone and T-2 Toxin on Calcitonin Gene Related Peptide-Like Immunoreactive (CGRP-LI) Neurons in the ENS of the Porcine Descending Colon. Toxins 2017, 9, 98. [CrossRef] [PubMed] 
15. Bovo, F.; Corassin, C.H.; Rosim, R.E.; De Oliveira, C.A.F. Efficiency of Lactic Acid Bacteria Strains for Decontamination of Aflatoxin M1 in Phosphate Buffer Saline Solution and in Skimmed Milk. Food Bioprocess Technol. 2012, 6, 2230-2234. [CrossRef]

16. Avantaggiato, A.; Solfrizzo, M.; Visconti, A. Recent advances on the use of adsorbent materials for detoxification of Fusarium mycotoxins. Food Addit. Contam. 2005, 22, 379-388. [CrossRef]

17. Council for Agricultural Science and Technology. Mycotoxins: Risks in Plant, Animal, and Human Systems, 1st ed.; CAST: Ames, IA, USA, 2003.

18. Calado, T.; Venâncio, A.; Abrunhosa, L. Irradiation for Mold and Mycotoxin Control: A Review. Compr. Rev. Food Sci. Food Saf. 2014, 13, 1049-1061. [CrossRef]

19. Di Gregorio, M.C.; De Neeff, D.V.; Jager, A.V.; Corassin, C.H.; Carão, C.D.P.A.; De Albuquerque, R.; De Azevedo, A.C.; Oliveira, C.A.F. Mineral adsorbents for prevention of mycotoxins in animal feeds. Toxin Rev. 2014, 33, 125-135. [CrossRef]

20. Lyagin, I.; Efremenko, E. Enzymes for Detoxification of Various Mycotoxins: Origins and Mechanisms of Catalytic Action. Molecules 2019, 24, 2362. [CrossRef]

21. Bello, M.L.; Junior, A.M.; Vieira, B.A.; Dias, L.R.S.; De Sousa, V.P.; Castro, H.C.; Rodrigues, C.R.; Cabral, L.M. Sodium Montmorillonite/Amine-Containing Drugs Complexes: New Insights on Intercalated Drugs Arrangement into Layered Carrier Material. PLoS ONE 2015, 10, e0121110. [CrossRef]

22. Massaro, M.; Colletti, C.G.; Lazzara, G.; Riela, S. The Use of Some Clay Minerals as Natural Resources for Drug Carrier Applications. J. Funct. Biomater. 2018, 9, 58. [CrossRef]

23. Wei, J.-T.; Wu, K.-T.; Sun, H.; Khalil, M.M.; Dai, J.-F.; Liu, Y.; Liu, Q.; Zhang, N.-Y.; Qi, D.-S.; Sun, L.-H. A Novel Modified Hydrated Sodium Calcium Aluminosilicate (HSCAS) Adsorbent Can Effectively Reduce T-2 Toxin-Induced Toxicity in Growth Performance, Nutrient Digestibility, Serum Biochemistry, and Small Intestinal Morphology in Chicks. Toxins 2019, 11, 199. [CrossRef] [PubMed]

24. Nazir, M.S.; Mohamad Kassim, M.H.; Mohapatra, L.; Gilani, M.A.; Raza, M.R.; Majeed, K. Nanoclay Reinforced Polymer Composites; Engineering Materials 2016; Springer Science: Singapore, 2016; pp. 35-50.

25. Huang, F.-C.; Lee, J.-F.; Lee, C.-K.; Chao, H.-P. Effects of cation exchange on the pore and surface structure and adsorption characteristics of montmorillonite. Colloids Surfaces A Physicochem. Eng. Asp. 2004, 239, 41-47. [CrossRef]

26. Zaghouane-Boudiaf, H.; Boutahala, M. Preparation and characterization of organo-montmorillonites. Application in adsorption of the 2,4,5-trichlorophenol from aqueous solution. Adv. Powder Technol. 2011, 22, 735-740. [CrossRef]

27. Dambolena, S.J.; Zunino, P.M.; López, G.A.; Rubinstein, R.H.; Zygadlo, A.J.; Mwangi, W.J.; Thoithi, N.G.; Kibwage, O.I.; Mwalukumbi, M.J.; Kariuki, T.S. Essential oils composition of Ocimum basilicum L. and Ocimum gratissimum L. from Kenya and their inhibitory effect on growth and fumonisin production by verticillioides. Innov. Food Sci. Emerg. Technol. 2010, 11, 239-422. [CrossRef]

28. Atanda, O.O.; Olopade, T.A. Effect of lemon grass (Cymbopogon citratus (DC) Stapf.) treatments on Aspergillus flavus (SGS-421) infestation and aflatoxin B 1 content of maize grains. Int. Food Res. J. 2013, 20, 1933-1939.

29. Olorunnisola, S.K.; Asiyanbi, H.T.; Hammed, A.M.; Simsek, S. Biological properties of lemongrass: An overview. Int. Food Res. J. 2014, 21, 455-462.

30. Fandohan, P.; Gnonlonfin, B.; Laleye, A.; Gbenou, J.; Darboux, R.; Moudachirou, M. Toxicity and gastric tolerance of essential oils from Cymbopogon citratus, Ocimum gratissimum and Ocimum basilicum in Wistar rats. Food Chem. Toxicol. 2008, 46, 2493-2497. [CrossRef]

31. Sun, X.-F.; Xu, F.; Sun, R.; Fowler, P.; Baird, M. Characteristics of degraded cellulose obtained from steam-exploded wheat straw. Carbohydr. Res. 2005, 340, 97-106. [CrossRef]

32. Lambert, J.B.; Mazzola, E.P. Nuclear Magnetic Resonance Spectroscopy: An Introduction to Principles, Applications, and Experimental Methods; Wiley: Hoboken, NJ, USA, 2019.

33. Lawal, I.A.; Moodley, B. Synthesis, characterization and application of imidazolium-based ionic liquid modified montmorillonite sorbents for the removal of amaranth dye. RSC Adv. 2015, 5, 61913-61924. [CrossRef]

34. Kandel, R. Potential for Using Aluminosilicates for Removal of Heavy Metals and Mycotoxins from Feed and Water. Master's Thesis, Norwegian University of Life Sciences, Norway, May 2018. Available online: https://pdfs.semanticscholar.org/ (accessed on 5 July 2019). 
35. Erminawati, R.N.; Sitoresmi, I.; Sidik, W.; Bachtiar, A. Antioxidant activity of microencapsulated lemongrass (Cymbopogon citratus) extract. In IOP Conference Series: Earth and Environmental Science; IOP Publishing: Bristol, UK, 2019; Volume 250, p. 012054.

36. Prins, C.L.; Freitas, S.D.P.; Gomes, M.D.; Vieira, I.J.C.; Gravina, G.D.A. Citral accumulation in Cymbopogon citratus plant as influenced by N6- benzyl amino purine and light intensity. Theo. Exp. Plant Phys. 2013, 25, 159-165. [CrossRef]

37. Sirhan, A.Y.; Tan, G.H.; Wong, R.C.S. Simultaneous detection of type A and type A trichothecenes in cereals by liquid chromatography coupled with electrospray ionization quadrupole time of flight mass spectrometry (LC-ESI-QTOF-MS/MS). J. Liq. Chromatogr. Relat. Technol. 2012, 35, 1945-1957. [CrossRef]

38. Cserhati, M.; Kriszt, B.; Krifaton, C.; Szoboszlay, S.; Hahn, J.; Toth, S.; Nagy, I.; Kukolya, J. Mycotoxindegradation profile of Rhodococcus strains. Int. J. Food Microbiol. 2013, 166, 176-185. [CrossRef] [PubMed]

39. Wachowska, U.; Packa, D.; Wiwart, M. Microbial Inhibition of Fusarium Pathogens and Biological Modification of Trichothecenes in Cereal Grains. Toxins 2017, 9, 408. [CrossRef] [PubMed]

40. Wu, J.; Zhou, Y.; Yuan, Z.; Yi, J.; Chen, J.; Wang, N.; Tian, Y. Autophagy and Apoptosis Interact to Modulate T-2 Toxin-Induced Toxicity in Liver Cells. Toxins 2019, 11, 45. [CrossRef] [PubMed]

41. Oranusi, S.; Braide, W.; Nwodo, C.F.; Nwosu, U.P. Assay for Aflatoxins in some local food condiments. Int. J. Biol. Pharm. Allied Sci. 2013, 2, 529-537.

42. Ojewumi, M.E.; Banjo, M.G.; Oresegun, M.O.; Ogunbiyi, T.A.; Ayoola, A.A.; Awolu, O.O.; Ojewumi, E.O. Analytical investigation of the extract of lemongrass leaves in repelling mosquito. Int. J. Pharm. Sci. Res. 2017, 8, 2048-2055.

43. Olopade, B.K.; Oranusi, S.U.; Nwinyi, O.C.; Njobeh, P.B.; Lawal, I.A. Modification of montmorillonite clay with Cymbopogon citratus for the decontamination of zearalenone in millet. AIMS Agric. Food 2019, 4, 643-657. [CrossRef]

44. Noudem, J.A.; Nguemtchouin Mbouga, M.G.; Kaptso, K.G.; Khalfaoui, M.; Noumi, G.B. Saponins-clay modified materials: A new approach against Callosobruchus subinnotatus in stored products. Int. J. Sci. Technol. Res. 2017, 6, 134-141.

45. Sulyok, M.; Berthiller, F.; Krska, R.; Schuhmacher, R. Development and validation of a liquid chromatography/ tandem mass spectrometric method for the determination of 39 mycotoxins in wheat and maize. Rapid Commun. Mass Spectrom. 2006, 20, 2649-2659. [CrossRef] 